\title{
A Case Study to Create Indonesian International Enterpreneurship by on Job Training in Europe
}

\author{
Jamhadi, Haryo Santosa, Iwan Tjahjo \\ Management \\ STIE IEU \\ Surabaya, Indonesia \\ jamhadi@ieu.ac.id; haryo.santosa@ieu.ac.id
}

\begin{abstract}
In usual to create an entrepreneurship start with micro/small enterprise. In STIE IEU Surabaya student are familiarized with global culture and discuss everyday on big enterprises or Multinational Corporation. The course for export always by ending teleconference or trading with other country in Japan, European, Middle East, China, USA. In summer course student go to Europhean to do special on the job training. The program include how to run a business, Europhean banking, supply chain management, harbor management and comparative study on diamond business and other corporation . After ending program the student are familiarized with global trading and competent to make business in big scale or Multinational Corporation. This research use qualitative analysis with cooperation International Management Institute (IMI) Anwernpen Belgium. The result of research to create international entrepreneur.
\end{abstract}

\section{Keywords ; familiarized, international entrepreneurship}

\section{INTRODUCTION}

In major of university held entrepreneurship student learned business start with micro / small enterprise. But because of limited time in facing globalization example Asean Free Trade Area (AFTA) 2015 new method to create entrepreneurships must be made. The new alternative is to make student familiar write global culture and every day to solve the problem of the big or multinational corporation. Because of the scale of the enterprise, there for the model of the early career choice of chief executive are used before to become owners.

Are entrepreneurships born or made? Can entrepreneurship be learned? If entrepreneurs were a gift people were born with, the way they are born with a gift for music or an eye for painting, we would be in bad shape. For we know that only a small minority is born with great gifts in any one of these areas. We would therefore be reduced to trying to spot people with high potential of entrepreneurship early and to train them as best we know to develop their talent. But we could hardly hope to find enough people for the executive tasks or modern society this way. Indeed, if entrepreneurs were a gift, our present civilization would be highly vulnerable, if not untenable. As a civilization of large organizations it is depend-ent on a large supply of people capable of being executives with a modicum of entrepreneurs.

It entrepreneurship can be learned, however, the questions arise: What does it consists in? What does one have to learn?
Of what kind is the learning? Is it a knowledge - and knowledge one learns in systematic form and through concepts? Is it a skill which one learns as an apprentice? Or is it a practice which one learns through doing the same elementary things over and over again?

\section{DATA AND METHODS}

Despite much discussion these days of the "entrepreneurial personality ", few of the entrepreneurs with whom I have worked during the past 30 years had such personalities. But I have known many people-salespeople, surgeons, journalists, scholar, even musicians-who did have them without being the least bit entrepreneurial. What all the successful entrepreneurs I have met have in common is not a certain kind of personality but a commitment to the systematic practice of innovation [1].

Innovation is the specific function of entrepreneurship, whether in an existing business, a public service institution, or a new venture started by a lone individual in the family kitchen. It is the means by which the entrepreneur either creates new wealth-producing resources or endow existing resources with enhanced potential for creating wealth.

Today, much confusion exists about the proper definition of entrepreneurship. Some observers use the term to all small businesses; others, to all new businesses. In practice, however, a great many well-established businesses engage in highly successful entrepreneurship. The term, then, refers not to an enterprise's size or age but to a certain kind of activity. At the heart of that activity is innovation; the effort to create purposeful, focused change in enterprises economic or social potential.

\section{Sources of Innovation}

There are, of course, innovations that spring from a flash of genius. Most innovation, however, especially the successful ones, result from a conscious, purposeful search for innovation opportunities, which are found only in a few situations. Four such areas of opportunity exist within a company or industry: unexpected occurrences, incongruities, process needs, and industry and market changes.

Three additional sources of opportunity exist outside a company in its social and intellectual environment; 
demographic changes, changes in perception, and new knowledge.

True, these sources overlap, different as they may be in the nature of their risk, difficulty, and complexity and the potential for innovation may well lie in more than one area at a time. But together, they account for the great majority of all innovation opportunities.

\section{RESULT AND DISCUSSION}

There is no perfect educational course which will prepare executives/entrepreneurs for a successful career. Indeed, we choose several ways; graduate I, graduate II, graduate III from viney diagram for prepare students for a successful.

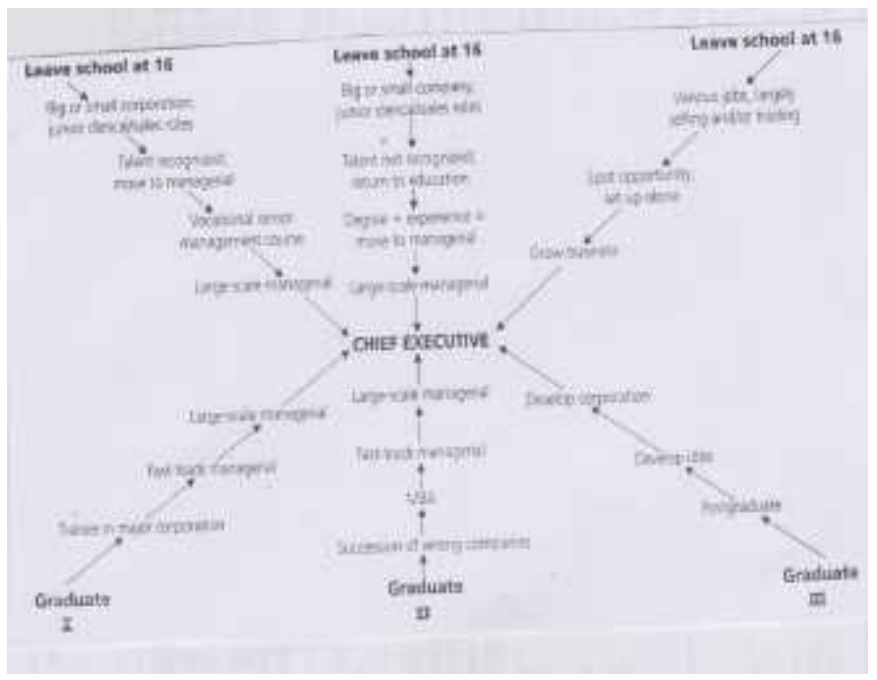

Picture 1. Viney Diagram

Implementation for Practice: are:

To make student familiar with global culture, the program
- The course for export by tele conference. The trading with Europhean, Japan, Middle East, China, USA. The lecturer have experience to make exhibition for export around the world. The other lecturer have branch office in USA and other.

- In summer course student go to Europhean to do special on the job training. The program include how to run a business, Europhean banking, supply chain management, harbor management and comparative study on diamond business and other corporation. After ending program the student are familiarized with global trading and competent to make business in big scale or Multinational Corporation.

\section{CONCLUSION}

After finish of the program, student familiar with global culture, increase self-confidence, good entrepreneurial personality and ready in facing globalization.

Entrepreneurship, in other word is a habit, that is a complex of practices and practices can always be learned. But practices are always exceedingly hard to do well. Practices one learns by practicing and practicing and practicing again.

\section{ACKNOWLEDGMENT}

The researcher say thanks for everyone that give me support, help and anything in order to this research can implemented, success and give benefit for all everyone.

\section{REFERENCES}

[1] Drucker., P, The Effective Executive. London: Pan Books Ltd, 1970.

[2] Drucker., P, The Dicipline of Innovation on Innovation. New York: Harvard Business School Publishing Corporation, 2013

[3] Viney.J, Go You Dream of Being a Chief Executive? The Route to The Top. New York: A John Wiley \& Sons Co, 2002 